\title{
Developmental regulation of GABAergic signalling in the hippocampus of neuroligin 3 R451C knock-in mice: an animal model of Autism
}

\author{
Rocco Pizzarelli and Enrico Cherubini* \\ Department of Neuroscience, Scuola Internazionale Superiore di Studi Avanzati, Trieste, Italy
}

Edited by:

Yosef Yarom, Hebrew University, Israel

\section{Reviewed by:}

Maarten H. P. Kole, Netherlands

Institute for Neuroscience,

Netherlands

Yehezkel Ben-Ari, Institut National de la Santé et de la Recherche

Médicale, France

\section{*Correspondence:}

Enrico Cherubini, Department of Neuroscience, Scuola Internazionale Superiore di Studi Avanzati, Via Bonomea 265, 34136 Trieste, Italy

e-mail: cher@sissa.it
Autism Spectrum Disorders (ASDs) comprise an heterogeneous group of neuro-developmental abnormalities, mainly of genetic origin, characterized by impaired social interactions, communications deficits, and stereotyped behaviors. In a small percentage of cases, ASDs have been found to be associated with single mutations in genes involved in synaptic function. One of these involves the postsynaptic cell adhesion molecule neuroligin (NL) 3. NLs interact with presynaptic neurexins (Nrxs) to ensure a correct cross talk between post and presynaptic specializations. Here, transgenic mice carrying the human R451C mutation of N/gn3, were used to study GABAergic signaling in the hippocampus early in postnatal life. Whole cell recordings from CA3 pyramidal neurons in slices from NL3 ${ }^{\mathrm{R} 451 \mathrm{C}}$ knock-in mice revealed an enhanced frequency of Giant Depolarizing Potentials (GDPs), as compared to controls. This effect was probably dependent on an increased GABAergic drive to principal cells as demonstrated by the enhanced frequency of miniature $\mathrm{GABA}_{A}$-mediated (GPSCs), but not AMPA-mediated postsynaptic currents (EPSCs). Changes in frequency of mGPSCs were associated with an acceleration of their decay kinetics, in the absence of any change in unitary synaptic conductance or in the number of $\mathrm{GABA}_{A}$ receptor channels, as assessed by peak scaled non-stationary fluctuation analysis. The enhanced GABAergic but not glutamatergic transmission early in postnatal life may change the excitatory/inhibitory balance known to play a key role in the construction and refinement of neuronal circuits during postnatal development. This may lead to behavioral deficits reminiscent of those observed in ASDs patients.

Keywords: neuroligin 3 mutation, developing hippocampus, GDPs, miniature GABAergic events, autism

\section{INTRODUCTION}

Autism Spectrum Disorders (ASDs) comprise a heterogeneous group of pathological conditions characterized by impaired social interactions, deficits in verbal and non verbal communication, limited interest in the surrounding environment associated with stereotyped and repetitive behavior (American Psychiatric Association, 2000). ASDs are among the most heritable neurodevelopmental disorders with a high incidence in infancy and early childhood (Weintraub, 2011). It is believed that the genetic predisposition together with environmental factors contribute to alter normal brain development leading to an impaired connectivity between brain regions, ultimately weakening the specialized functions of cortical areas (Geschwind and Levitt, 2007).

Interestingly, a small percentage of cases with idiopathic ASDs have been found to be associated with single mutations in genes involved in synapses organization, pointing to synaptic dysfunction as one possible cause of autism (Südhof, 2008). Among these, mutations of genes encoding for cell adhesion molecules of the neuroligin (NL; Jamain et al., 2003; Laumonnier et al., 2004; Yan et al., 2005), neurexin (Nrx; Kim et al., 2008) families or for SHANK3, a scaffold protein involved in the structural organization of dendritic spines and a binding partner of NLs (Durand et al., 2007), have received particular attention. Nrxs and NLs bridge the cleft thus providing the functional link between pre- and post-synaptic elements of the synapse. Over-expression of NLs in non-neuronal cells co-cultured with neurons induces structural differentiation of both excitatory and inhibitory presynaptic terminals in contacting axons (Scheiffele et al., 2000; Fu et al., 2003; Graf et al., 2004; Sara et al., 2005). Conversely, Nrxs trigger postsynaptic differentiation by aggregating NLs and neurotransmitter receptors on the dendritic surface (Graf et al., 2004). The bidirectional signaling through the NL-Nrx is crucial for synapse development and stabilization (Scheiffele et al., 2000; Varoqueaux et al., 2006; Chubykin et al., 2007; Ko et al., 2009; Poulopoulus et al., 2009).

Interestingly, one missense mutation causing R451C substitution within a highly conserved region of the extracellular esterase-homology domain of the Nlgn 3 gene was detected in two male siblings, one with autism, severe intellectual disabilities and seizures and the other with Asperger syndrome (Jamain et al., 2003). To gain insights into the possible mechanisms of ASDs, this mutation was introduced into the endogenous Nlgn 3 in mice by 
gene targeting (Tabuchi et al., 2007). Previous work from juvenile and adult NL3 ${ }^{\mathrm{R} 451 \mathrm{C}}$ knock-in mice have revealed deficits in social interaction, reminiscent of those found in ASDs patients, associated with modifications in GABAergic (Tabuchi et al., 2007) and glutamatergic (Etherton et al., 2011) synaptic transmission.

These studies, however, did not address the question whether the R451C mutation of NL3 affects GABAergic signaling at early developmental stages when GABA exerts a critical role in synapse formation and stabilization (Pizzarelli and Cherubini, 2011). This information is important because developmental disorders such as ASDs can be diagnosed early in infancy when an immediate therapeutic intervention may maximize potential benefits.

We examined synaptic transmission in the CA3 hippocampal area during the first 2 weeks of postnatal life when rapid morphological changes occur at both pre and postsynaptic levels (Amaral and Dent, 1981) and in adulthood. We found that the R451C mutation selectively affects GABAergic signaling and correlated network activity from birth.

\section{MATERIALS AND METHODS ETHICAL APPROVAL}

All experiments were performed in accordance with the European Community Council Directive of November 24, 1986 (86/609EEC) and were approved by the local authority veterinary service and by SISSA ethical committee. All efforts were made to minimize animal suffering and to reduce the number of animal used.

\section{ANIMALS}

NL3 ${ }^{\text {R451C }}$ mice (Tabuchi et al., 2007) were purchased from Jackson Laboratories (Maine, USA). Experiments were performed on off-spring male derived from heterozygous mating. Electrophysiological experiments were performed and analyzed blind before genotyping. This was carried out on tail biopsy DNA by PCR using a standard protocol. At least three mice for each genotype were used in a given experiment.

\section{HIPPOCAMPAL SLICE PREPARATION}

Transverse hippocampal slices (300-400 $\mu \mathrm{m}$ tick) were obtained from neonatal (postnatal day 4-9) young (postnatal day 11-15) and adult (postnatal day 27-35) mice using a standard protocol (Griguoli et al., 2010). Briefly, after being anesthetized with $\mathrm{CO}_{2}$, animals were decapitated. The brain was quickly removed from the skull and placed in ice-cold artificial cerebrospinal fluid (ACSF) containing (in mM): $130 \mathrm{NaCl}, 25$ glucose, $3.5 \mathrm{KCl}, 1.2$ $\mathrm{NaH}_{2} \mathrm{PO}_{4}, 25 \mathrm{NaHCO}_{3}, 2 \mathrm{CaCl}_{2}$, and $1.3 \mathrm{MgCl}_{2}$, saturated with 95\% $\mathrm{O} 2$ and 5\% $\mathrm{CO}_{2}$ ( $\left.\mathrm{pH} 7.3-7.4\right)$. Transverse hippocampal slices were cut with a vibratome and stored at room temperature $\left(22-24^{\circ} \mathrm{C}\right)$ in a holding bath containing the same solution as above. After incubation for at least $45 \mathrm{~min}$, an individual slice was transferred to a submerged recording chamber and continuously superfused at $33-34^{\circ} \mathrm{C}$ with oxygenated ACSF at a rate of $3-4 \mathrm{ml} / \mathrm{min}$.

\section{ELECTROPHYSIOLOGICAL RECORDINGS}

Recordings were made with a patch-clamp amplifier (Axopatch 1D amplifier, Axon Instruments, Sunnyvale, CA, USA) from CA3 pyramidal cells visualized with an upright microscope equipped with differential interference contrast optics and infrared video camera, using the whole cell configuration of the patch-clamp technique. Patch electrodes were pulled from borosilicate glass capillaries (Hingelberg, Malsfeld, Germany); when filled with an intracellular solution they had a resistance of 4-6 M $\Omega$. The stability of the patch was checked by repetitively monitoring the input and series resistance during the experiments. Cells exhibiting 15\% changes were excluded from the analysis. The series resistance was $<25 \mathrm{M} \Omega$.

Spontaneous glutamatergic and GABAergic postsynaptic currents were routinely recorded from a holding potential of $-65,-70 \mathrm{mV}$ in the presence of bicuculline $(10 \mu \mathrm{M})$ and DNQX $(20 \mu \mathrm{M})$, respectively. Miniature currents were recorded in the presence of TTX $(1 \mu \mathrm{M})$ to block sodium currents and propagated action potentials. For glutamatergic currents we used an intracellular solution containing (in $\mathrm{mM}$ ): 125 Csmethanesulphonate, $10 \mathrm{CsCl}$, 10 HEPES, 0.3 EGTA, 2 MgATP, 0.3 $\mathrm{NaGTP}$, ( $\mathrm{pH}$ adjusted to $\sim 7.3$ with $\mathrm{CsOH}$ ). For GABAergic currents we used an intracellular solution containing (in $\mathrm{mM}$ ): $\mathrm{CsCl}$ 137, Hepes 10, BAPTA 11, MgATP 2, $\mathrm{MgCl}_{2} 2, \mathrm{CaCl}_{2} 1$ and 5 QX-314 ( $\mathrm{pH}$ adjusted to $\sim 7.3$ with $\mathrm{CsOH}$ ).

Concentric bipolar electrodes were used to stimulate granule cells in the dentate gyrus in order to elicit 2-amino-3-(5-methyl3-oxo-1,2-oxazol-4-yl) propanoic acid (AMPA)-mediated excitatory postsynaptic currents (EPSCs) in CA3 pyramidal neurons (frequency of stimulation: $0.1 \mathrm{~Hz}$; stimulus duration 100-200 $\mu \mathrm{s}$ ). Stimulus strength was adjusted to obtain at $-65 \mathrm{mV}$ stable EPSCs of $\sim 100 \mathrm{pA}$ amplitude. The NMDA component was recorded from the same neuron at $+40 \mathrm{mV}$, using the same stimulus strength, after blocking the AMPA-mediated component with DNQX $(20 \mu \mathrm{M})$. While AMPA-mediated EPSCs were recorded close to the reversal potential of GABA, NMDA currents were elicited in the presence of DNQX $(20 \mu \mathrm{M})$ and bicuculline $(10 \mu \mathrm{M})$ to block AMPA and $\mathrm{GABA}_{\mathrm{A}}$ receptors, respectively.

In some experiments, extracellular field potentials were recorded using conventional glass microelectrodes (tip diameter 5-10 $\mu \mathrm{M}$ ) filled with ACSF and placed into the stratum pyramidale of the CA3 area.

\section{DRUGS}

The following drugs were used: 6,7-Dinitroquinoxaline-2,3-dione (DNQX), 6-Imino-3-(4-methoxyphenyl)-1(6H)-pyridazinebutanoic acid (SR 95531) hydrobromide, picrotoxin and bicuculline, purchased from Ascent Scientific; (1,2,5,6Tetrahydropyridin-4-yl)met hylphosphinic acid (TPMPA) and $\quad \mathrm{N}$-(2,6-Dimethylphenylcarbamoylmethyl) triethylammonium bromide (QX 314), purchased from Tocris Bioscence; tetrodotoxin (TTX) from Latoxan. Bumetanide and 1-[2-[[(Diphenylmethylene)imino $]$ oxy $]$ ethyl $]-1,2,5,6-$ tetrahydro-3-pyridinecarboxylic acid hydrochloride hydrochloride (NO-711), from Sigma-Aldrich. Zolpidem was a gift of Dr. A. Barberis (Italian Institute of Technology, Genova). Stock solutions were made in distilled water and then aliquoted and frozen at $-20^{\circ} \mathrm{C}$. DNQX and picrotoxin were dissolved in dimethylsulfoxide (DMSO). The final concentration of DMSO in the bathing solution was $0.1 \%$. At this concentration, 
DMSO alone did not modify the membrane potential, input resistance, or the firing properties of CA3 pyramidal neurons. Drugs were applied in the bath by gravity by changing the superfusion solution to one differing only in its content of $\operatorname{drug}(\mathrm{s})$. The ratio of flow rate to bath volume ensured complete exchange within 2-3 min.

\section{DATA ANALYSIS}

Data were acquired at $20 \mathrm{kHz}$, filtered with a cut-off frequency of $2 \mathrm{kHz}$ and stored on computer in order to perform off-line analysis. Miniature AMPA and $\mathrm{GABA}_{\mathrm{A}}$-mediated postsynaptic currents were analyzed using pClamp 10.0 (Molecular Devices, Sunnyvale, CA, USA). This program uses a detection algorithm based on a sliding template. The template did not induce any bias in the sampling of events because it was moved along the data trace by one point at a time and was optimally scaled to fit the data at each position. The detection criterion was calculated from the template-scaling factor and from how closely the scaled template fitted the data.

To minimize the contribution of the unquantifiable effects of cable filtering, detailed kinetic analysis of miniature synaptic currents was limited to events with a rise time $\leq 1 \mathrm{~ms}$. The rise time was estimated as the $10-90 \%$ time needed to reach the peak of the synaptic current. The weighted decay was obtained by dividing miniatures charge transfer by their amplitude.

The amplitude of the tonic current was estimated by the outward shift of the baseline current after the application of the $\mathrm{GABA}_{\mathrm{A}}$ receptor channel blocker picrotoxin $(100 \mu \mathrm{M})$. Only current recordings that exhibited a stable baseline were included in the analysis. Baseline currents and their standard deviations were estimated by plotting $10 \mathrm{~s}$ periods of raw data in all point histograms. These were fitted with a Gaussian function. The peak of the fitted Gaussian was considered as the mean holding current (Glykys and Mody, 2007).

NMDA/AMPA ratio was measured by averaging 15 to 30 sweeps for each holding potential. The AMPA-mediated component was measured at the peak of the current obtained at $-65 \mathrm{mV}$, while the NMDA component was measured at the peak of the current obtained at $+40 \mathrm{mV}$ after blocking the AMPA component with DNQX. The weighted decay time constant for NMDA-mediated synaptic current was measured by dividing the area by its amplitude, independently of the fitting (Cathala et al., 2003).

Peak scaled non-stationary noise analysis was performed according to Traynelis et al. (1993) using the Mini Analysis program (version 6.0.1, Synaptosoft, Leonia, NJ). Miniature events were selected following the procedure described by Momiyama et al. (2003). Briefly, individual events were analyzed by measuring the peak amplitude, the 10-90\% rise time and the decay time constant. Measured parameters were then numbered according to the event number and tested by Spearman's rank order correlation test for time stability. After testing for correlation between rise time and amplitude and between rise time and decay time, miniature GABAergic events were used for noise analysis. Individual events were aligned to the point of steepest rise time. The peak of the mean current response waveform was scaled to the response value at the corresponding point in time of each individual event before subtraction to generate the difference waveforms. The ensemble mean post synaptic current was binned into 50 bins of equal amplitude to assign similar weights to all phases of ensemble mean waveform. Variance was plotted against amplitude and individual points were fitted with the equation:

$$
\sigma^{2}(I)=i I-I^{2} / N+\sigma_{b}^{2}
$$

where $i$ is the unitary single-channel current, $I$ is the mean current, $N$ is the number of channels open at the current peak and $\sigma_{b}^{2}$ is the variance of the background noise. The single-channel chord conductance $(\gamma)$ was calculated as:

$$
\gamma=i /\left(E_{m}-E_{\mathrm{rev}}\right)
$$

from the holding potential $\left(E_{m}\right)$ of $-70 \mathrm{mV}$, assuming a reversal potential $\left(E_{\text {rev }}\right)$ of $0 \mathrm{mV}$.

\section{STATISTICAL ANALYSIS}

All values are presented as mean \pm SEM. In most of the experiments, statistical comparison was performed using the unpaired $t$-test. Due to the non-Gaussian distribution in the frequency and amplitude of miniature GABAergic and glutamatergic events, probability plots were compared using the Kolmogorov-Smirnov test. Significance between independent experimental groups was calculated using the One-Way ANOVA. Bonferroni post test was used to evaluate the statistically significance between paired groups within the multiple comparison. A $p$-value $<0.05$ was considered as statistically significant.

\section{RESULTS \\ SPONTANEOUS NETWORK-DRIVEN EVENTS ARE ENHANCED IN NL3 ${ }^{\text {R451C }}$ MICE}

We first examined the resting membrane potential $\left(V_{\text {rest }}\right)$ and the input resistance $\left(R_{\text {in }}\right)$ of the recording neurons (at P4-P9). No significant differences in these parameters were found between $\mathrm{WT}$ and $\mathrm{NL} 3^{\mathrm{R} 451 \mathrm{C}}$ mice $\left(V_{\text {rest }}:-50 \pm 2 \mathrm{mV}\right.$ and $-44 \pm 3 \mathrm{mV}$ in WT and NL3 ${ }^{\mathrm{R} 451 \mathrm{C}}$ mice, respectively; $R_{\text {in }}: 815 \pm 200 \mathrm{M} \Omega$ and $770 \pm 162 \mathrm{M} \Omega$ in $\mathrm{WT}$ and NL3 ${ }^{\mathrm{R} 451 \mathrm{C}}$ mice, respectively; $n=13$; $p>0.05$ for both $V_{\text {rest }}$ and $\left.R_{\text {in }}\right)$.

As ASDs are neurodevelopmental disorders, we first verified whether the $\mathrm{NL} 3^{\mathrm{R} 451 \mathrm{C}}$ mutation alters correlated network activity, the so-called Giant Depolarizing Potentials (GDPs), a hallmark of developmental networks (Ben-Ari et al., 1989, 2007). GDPs which represent a primordial form of synchrony between neurons, thought to be essential for proper circuit maturation (Ben-Ari et al., 2007; Blankenship and Feller, 2010), are generated by the synergistic action of glutamate and GABA, both of which are depolarizing and excitatory at early development stages (Cherubini et al., 1991).

We focused on the CA3 region of the hippocampus where GABAergic interneurons are centrally involved in GDPs generation (Bonifazi et al., 2009; Picardo et al., 2011; Allene et al., 2012). GDPs were recorded at P4-P9 simultaneously from single cells and from population of neurons as extracellular field potentials (Figures 1A,B). 


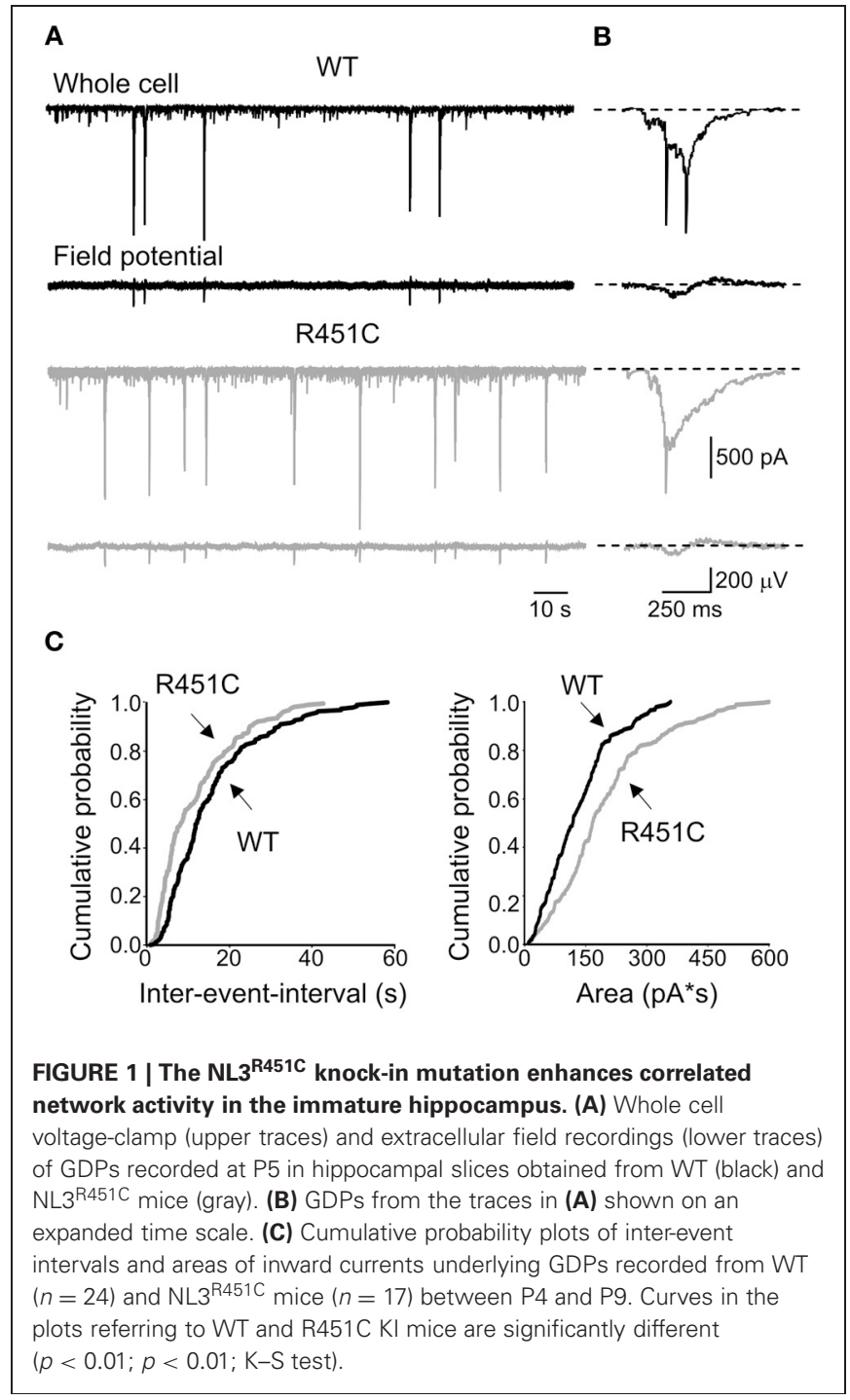

GDPs occurred more frequently in NL3 $3^{\mathrm{R} 451 \mathrm{C}}$ knock-in mice respect to WT $(0.69 \pm 0.009 \mathrm{~Hz}, n=17$, and $0.046 \pm 0.006 \mathrm{~Hz}$, $n=24$ in knock-in and control mice, respectively; $p<0.05$; unpaired $t$-test). As shown in the cumulative inter-event-interval plot of Figure 1C, the curve obtained from NL3 ${ }^{\mathrm{R} 451 \mathrm{C}}$ knockin mice was shifted to the left respect to that obtained from WT animals ( $p<0.05 ; \mathrm{K}-\mathrm{S}$ test). In addition, as illustrated in Figure 1C, in NL3 ${ }^{\mathrm{R} 451 \mathrm{C}}$ knock-in mice the cumulative probability curve related to charge transfers through the currents underlying GDPs was shifted to the right respect to controls and was significantly different from that obtained from WT animals $(p<$ $0.01 ; \mathrm{K}-\mathrm{S}$ test). In accord with a previous study (Le Magueresse et al., 2006), GDPs became rare at P8-9 and disappeared after P10 in both WT and NL3 ${ }^{\text {R451C }}$ knock-in mice. To assess whether the depolarizing action of GABA was instrumental in triggering GDPs in both WT and NL3 ${ }^{\mathrm{R} 451 \mathrm{C}}$ knock-in mice, we tested the consequences of converting GABA action from depolarizing to hyperpolarizing by exposing the slices to bumetanide, a selective blocker of the cation-chloride cotransporter NKCC1, responsible for the accumulation of chloride inside the cell (Dzhala et al., 2005; Sipila et al., 2006; Safiulina et al., 2008). In agreement with a previous study (Safiulina et al., 2008), bumetanide $(10 \mu \mathrm{M})$ completely abolished GDPs recorded at P4-P9 from WT $(n=5)$ and $\mathrm{NL} 3^{\mathrm{R} 451 \mathrm{C}}$ knock-in $(n=3)$ mice (data not shown), indicating that during the first postnatal days the depolarizing action of GABA contributes to generate GDPs in both strains of animals.

\section{ENHANCED BASAL GABAergic BUT NOT GLUTAMATERGIC TRANSMISSION IN YOUNG NL3 ${ }^{\text {R451C }}$ KNOCK-IN MICE}

Since network dynamics rely on neuronal connectivity and GDPs are strictly dependent on the synergistic action of GABA and glutamate, both depolarizing and excitatory (Ben-Ari et al., 2007), we next examined whether changes in spontaneous miniature synaptic currents could account for the observed effects. Miniature $\mathrm{GABA}_{\mathrm{A}}$ - and AMPA-mediated postsynaptic currents (mGPSCs and mEPSCs, respectively) were recorded at three different postnatal ages (P4-P9, P11-P15, P27-P35) in the presence of TTX $(1 \mu \mathrm{M})$ and DNQX or bicuculline, respectively. As shown in Figure 2, significant differences in the inter-event intervals distributions (but not amplitude) of mGPSCs were observed in all groups examined ( $p<0.05$ for all three groups; K-S test).

In contrast, cumulative distribution plots of inter-eventintervals of mEPSCs recorded from $N L 3^{\mathrm{R} 451 \mathrm{C}}$ and WT mice were significantly different only at P28-P35 ( $p<0.05$; K-S test; Figure 3). No significant differences in cumulative amplitude distributions were observed between $\mathrm{NL} 3^{\mathrm{R} 451 \mathrm{C}}$ and WT mice $(p>$ 0.05 ; K-S test).

Altogether, these results strongly support the involvement of the NL3 ${ }^{\mathrm{R} 451 \mathrm{C}}$ mutation in the enhancement of GABAergic transmission at early stages of postnatal development.

Furthermore, to assess whether the NL3 ${ }^{\mathrm{R} 451 \mathrm{C}}$ mutation differentially affects AMPA- and NMDA-mediated synaptic transmission, AMPA- and NMDA-mediated postsynaptic currents evoked by granule cell stimulation were examined at P4-P9 from CA3 principal cells at $-65 \mathrm{mV}$ and $+40 \mathrm{mV}$, respectively. While AMPA-mediated EPSCs were recorded close to the reversal potential of GABA, NMDA currents were elicited in the presence of DNQX $(20 \mu \mathrm{M})$ and bicuculline $(10 \mu \mathrm{M})$ to block AMPA and $\mathrm{GABA}_{\mathrm{A}}$ receptors, respectively. No significant differences were observed in the NMDA/AMPA ratio between the two different genotypes (WT $0.24 \pm 0.06, n=6$; KI $0.28 \pm 0.04 n=4 ; p>$ 0.05 ; data not shown).

In addition, similar decay time values of NMDA-mediated EPSCs were detected in both genotypes (WT $88.17 \pm 6 \mathrm{~ms}, n=6$; $\left.\mathrm{NL}^{\mathrm{R} 451 \mathrm{C}} 85.1 \pm 20 \mathrm{~ms} ; n=4 ; p>0.05\right)$, indicating that at MFCA3 synapses the $\mathrm{NL} 3^{\mathrm{R} 451 \mathrm{C}}$ mutation does not alter glutamatergic synaptic transmission and the postsynaptic expression of NMDA receptor subunits.

In the following experiments we focused on the second postnatal week (P11-P15) which corresponds to the period of maximal synaptogenesis and NLs expression (Budreck and Scheiffele, 2007).

\section{THE NL3 ${ }^{\text {R451C }}$ KNOCK-IN MUTATION AFFECTS GABA RELEASE}

According to the quantal theory, the synaptic efficacy $E$, the mean amplitude of unitary GPSCs, can be defined as $E=m Q$, 


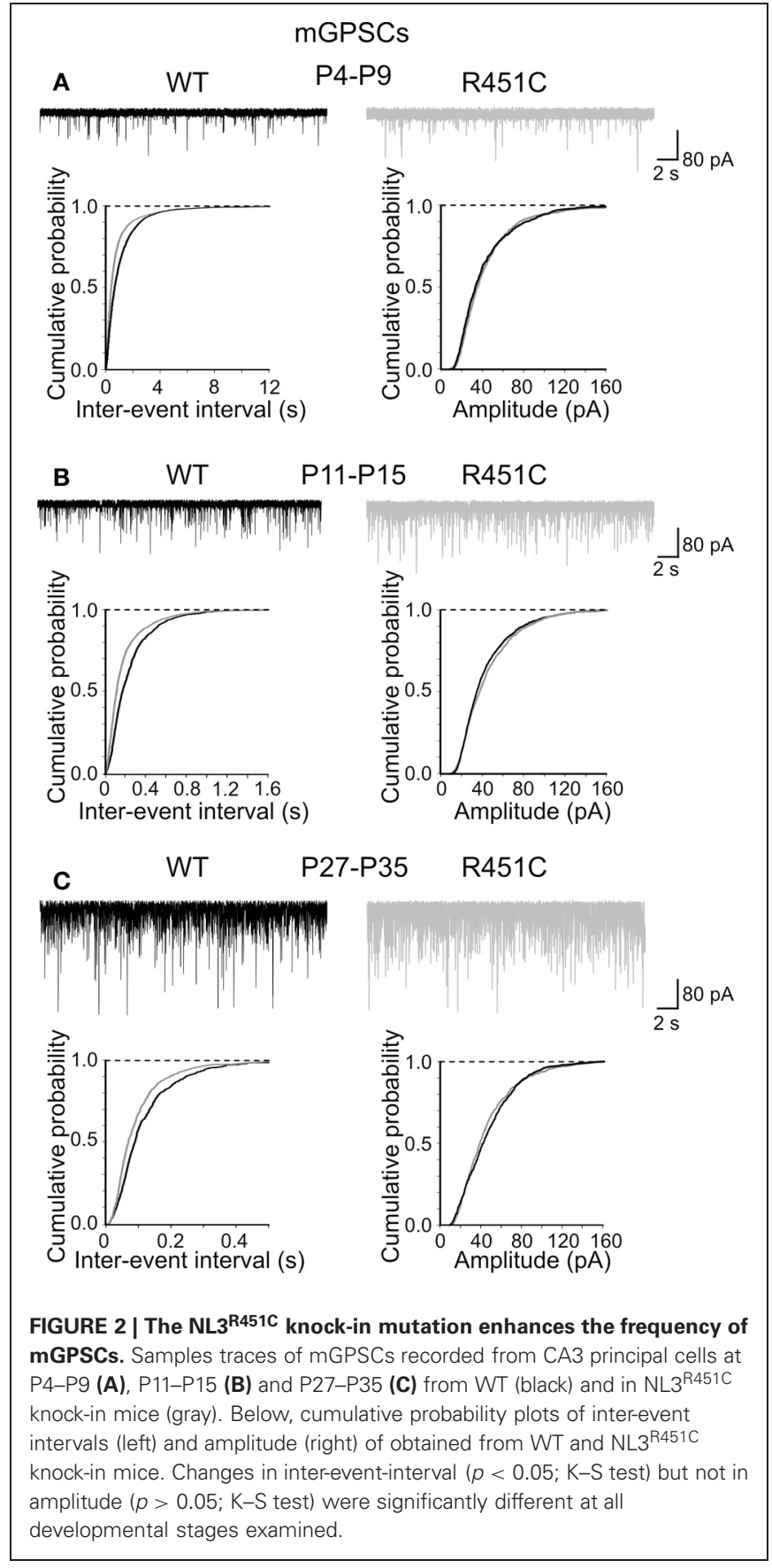

where $m$ is the quantal content or the mean number of quanta released per presynaptic action potential and $Q$ is the quantal size or amplitude of the unitary postsynaptic current (Katz, 1969). While $Q$ depends on both pre (GABA content in synaptic vesicles) and postsynaptic $\left(\mathrm{GABA}_{\mathrm{A}}\right.$ receptors) mechanisms, $m$ depends on presynaptic factors, namely the number of release sites $N$ and the probability of release $(P)$ at each individual site. Therefore, presynaptic changes in GABA release may be related to modifications either in $Q$ or $m$ or both.

To assess whether the increase in frequency of mGPSCs observed in $\mathrm{NL}^{\mathrm{R} 451 \mathrm{C}}$ mice is due to changes in GABA release,

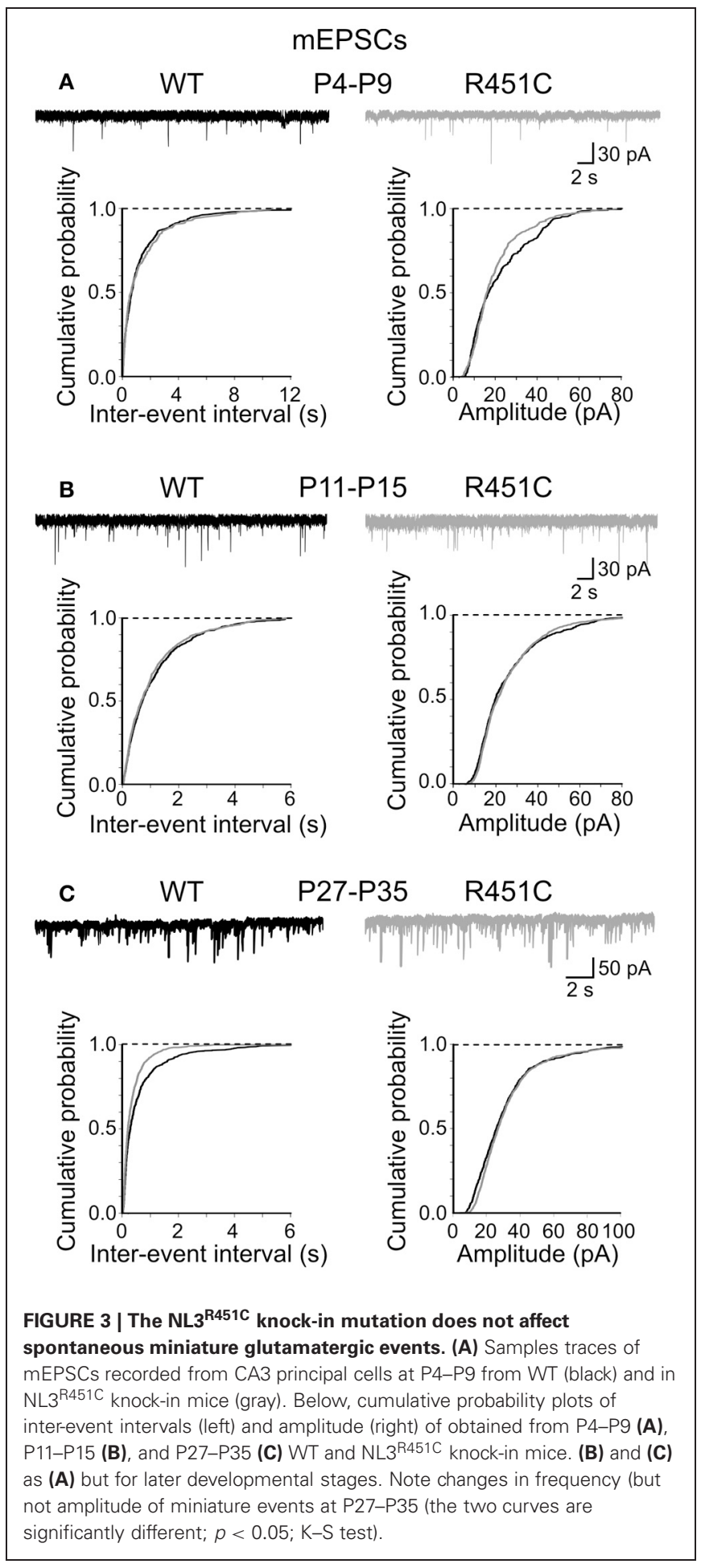

we analyzed GABA transients in the cleft. We took advantage of the low affinity competitive $\mathrm{GABA}_{\mathrm{A}}$ receptor antagonist TPMPA which has a very fast dissociation constant and competes with synaptically released GABA for the same ligand binding site on $\mathrm{GABA}_{\mathrm{A}}$ receptors (Jones et al., 2001; Barberis et al., 2004). This allowed us to compare differences in presynaptic GABA release between $\mathrm{WT}$ and $\mathrm{NL} 3^{\mathrm{R} 451 \mathrm{C}}$ mice, because the sensitivity 


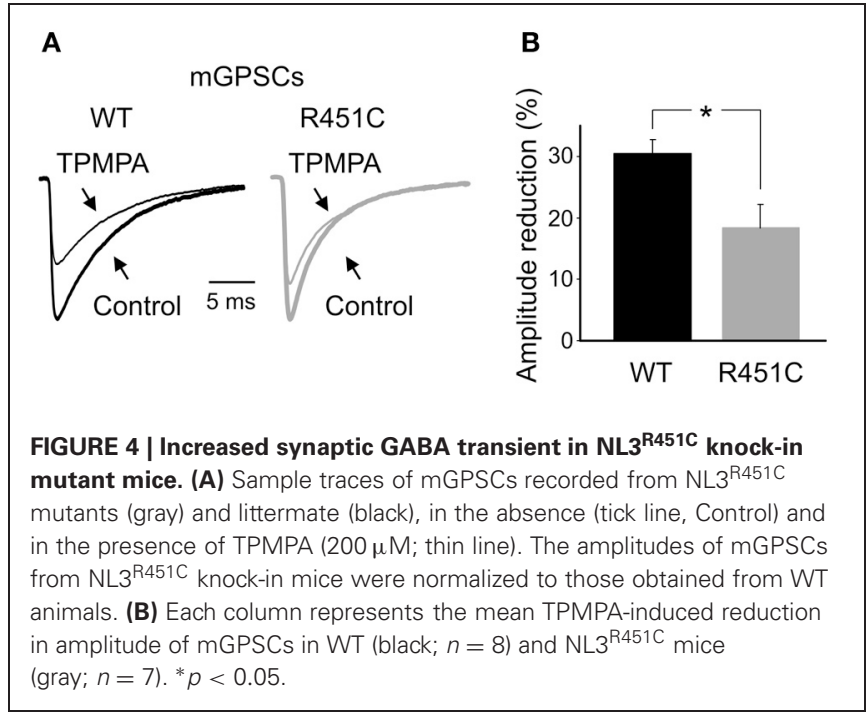

of mGPSCs to TPMPA block is strongly influenced by relative changes in GABA concentration, as both GABA and TPMPA compete for the same binding sites (Mozrzymas et al., 1999; Barberis et al., 2000; Jones et al., 2001). Bath application of TPMPA $(200 \mu \mathrm{M})$ caused a more pronounced reduction of mGPSCs amplitude in WT than in NL3 $3^{\mathrm{R} 451 \mathrm{C}}$ mice $(30.5 \pm 2.2 \% ; n=8$ and $18.4 \pm 3.7 \% ; n=7$ in WT and NL3 ${ }^{\mathrm{R} 451 \mathrm{C}}$ mice, respectively, $p<0.05$; One-Way ANOVA and Bonferroni post test for multi comparison analysis between groups), suggesting an increased GABA transient in the synaptic cleft of $N L 3^{\mathrm{R} 451 \mathrm{C}}$ mice respect to controls (Figure 4).

To test whether this effects was associated with an increased number of available $\mathrm{GABA}_{\mathrm{A}}$ receptors on the postsynaptic membrane (opened by a single GABA quantum, on the assumption that $\mathrm{GABA}_{\mathrm{A}}$ receptors are not saturated by the content of a single vesicle, Barberis et al., 2004), we used the peak-scaled non-stationary fluctuation analysis (see Methods; Traynelis et al., 1993). We used only stable recordings of mGPSCs with no timedependent changes in either peak amplitude, 10-90\% rise time and decay time (electrotonic filtering was excluded on the basis of no correlation between the $10-90 \%$ rise time and the decay time; Momiyama et al., 2003).

For each cell a parabolic variance vs. mean curve was obtained (see individual samples in Figures 5A,B). By fitting data points with Equation 1 gave an estimated unitary currents of $2 \pm 0.27 \mathrm{pA}$ and $2.6 \pm 0.25 \mathrm{pA}$ in WT and $\mathrm{NL} 3^{\mathrm{R} 451 \mathrm{C}}$ mice, respectively, corresponding to a weighted mean channel conductance of $29.2 \pm 3.8 \mathrm{pS}(n=8)$ and $37 \pm 3.5 \mathrm{pS}$ $(n=9)$. These values were not significantly different $(p>0.05$; Figure 5C). In addition, no significant differences in the number of $\mathrm{GABA}_{\mathrm{A}}$ receptor channels were found between WT and knock-in mice $(25.7 \pm 4.8, n=8$ and $22.4 \pm 2.1, n=9$, in WT and NL3 ${ }^{\mathrm{R} 451 \mathrm{C}}$ mice, respectively; $p>0.05$; Figure $5 \mathrm{C}$ ) indicating that changes in frequency of mGPSCs could not be attributed to modifications in the number of receptor channels opened at the peak of a spontaneous miniature GABAergic events.

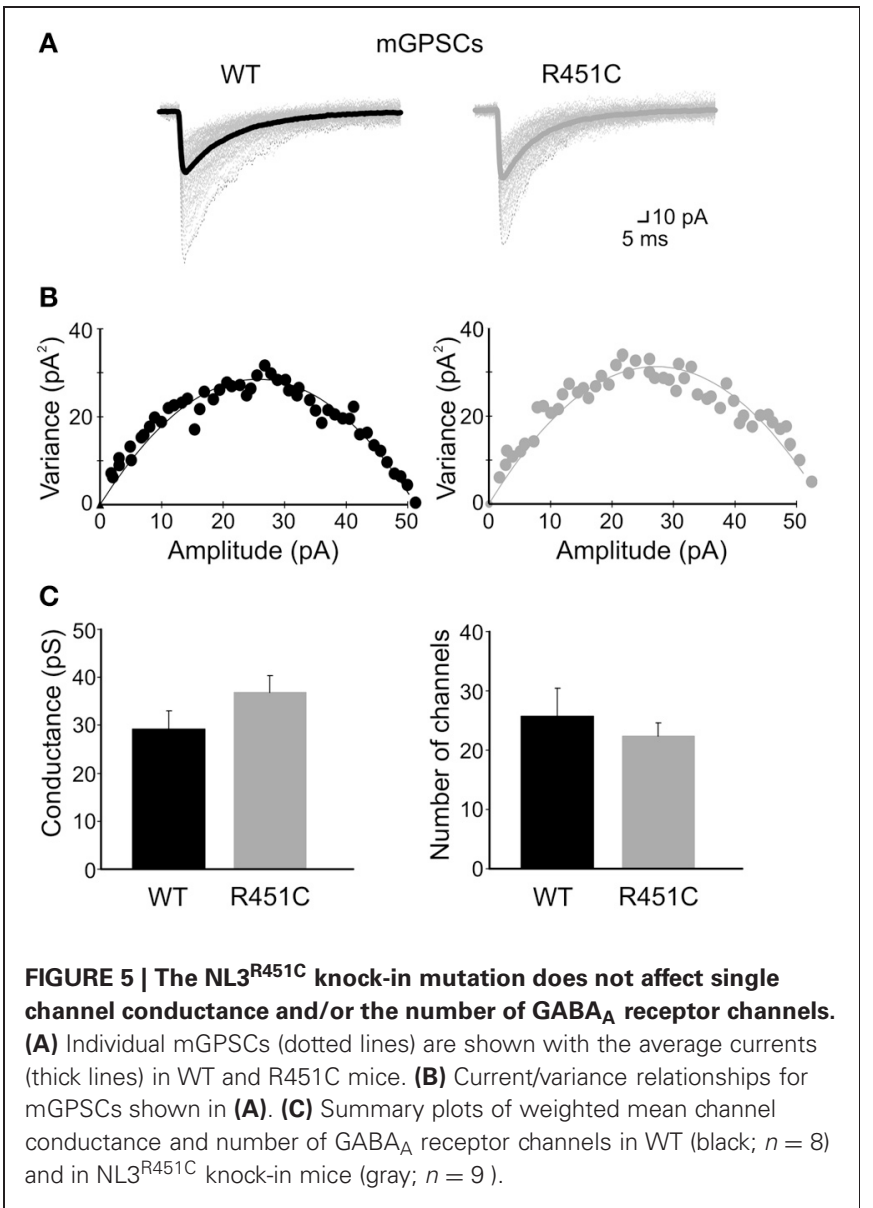

\section{THE NL3 ${ }^{\text {R451C }}$ KNOCK-IN MUTATION ALTERS THE DECAY KINETIC OF GABA $_{A}$ RECEPTORS}

Next, we examined the kinetic properties of miniature GABAeric events. As shown in Figure 6A, respect to WT animals, synaptic currents obtained from NL3 ${ }^{\mathrm{R} 451 \mathrm{C}} \mathrm{KI}$ mice at P9-P11 displayed a significantly $(p<0.05)$ faster decay time (the weighted decay time was $9.14 \pm 0.4 \mathrm{~ms} ; n=9$; and $7.43 \pm 0.5 \mathrm{~ms} ; n=9$; in WT and NL3 ${ }^{\mathrm{R} 451 \mathrm{C}}$ mice, respectively; in the absence of any change in the rise time $(0.53 \pm 0.02 \mathrm{~ms} ; n=9$; and $0.47 \pm$ $0.02 \mathrm{~ms} ; n=9$; in WT and NL3 $3^{\mathrm{R} 451 \mathrm{C}}$ mice, respectively; $p>$ 0.05). This led to a leftward shift of the cumulative probability curve obtained from $\mathrm{NL} 3^{\mathrm{R} 451 \mathrm{C}}$ respect to WT mice (the two cumulative curves were significantly different; $p<0.05, \mathrm{~K}-\mathrm{S}$ test; Figure 6B).

The faster decay time of mGPSCs observed in NL3 ${ }^{\mathrm{R} 451 \mathrm{C}}$ mice may result from a differential expression of $\mathrm{GABA}_{\mathrm{A}}$ receptor subunits in the postsynaptic membrane. One possibility is that the $\mathrm{NL}^{\mathrm{R} 451 \mathrm{C}}$ KI mutation accelerates the developmental switch from $\alpha 2$ to $\alpha 1$ subunits of $\mathrm{GABA}_{\mathrm{A}}$ receptors, known to produce currents with faster decay kinetics (Laurie et al., 1992; Cherubini and Conti, 2001). To elucidate whether in $\mathrm{NL} 3^{\mathrm{R} 451 \mathrm{C}}$ mice more $\alpha 1$ containing $\mathrm{GABA}_{\mathrm{A}}$ receptors are recruited at synapses respect to $\alpha 2$, we examined the prolongation of current decay induced by zolpidem, known to selectively enhance the activity of $\alpha 1$ subunit-containing receptors (Pritchett and Seeburg, 1990). Since 


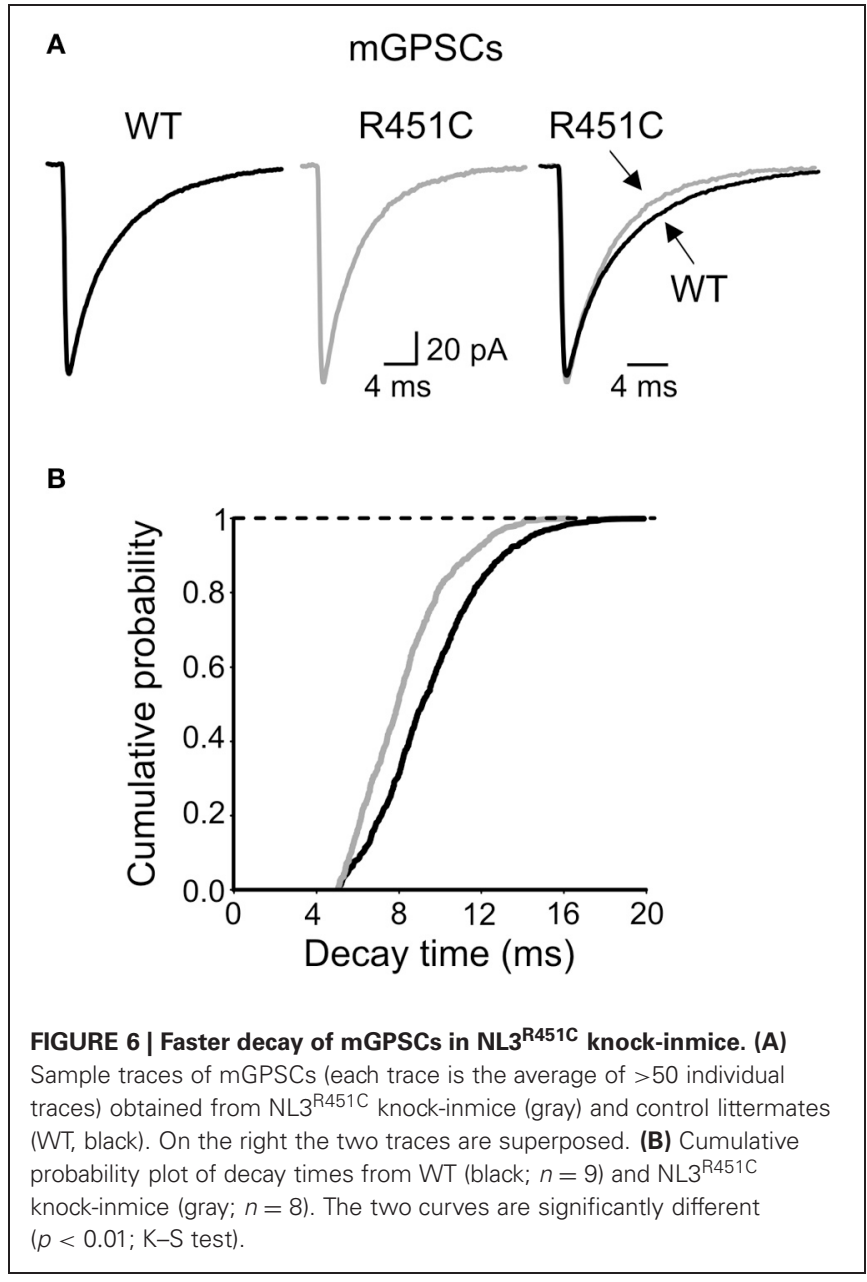

the effects of zolpidem on miniature GABAergic currents reflects the degree of receptor occupancy (Perrais and Ropert, 1999), we analyzed only mGPSCs duration. Application of zolpidem $(100 \mathrm{nM})$ prolonged the decay time of mGPSCs in both WT and $\mathrm{NL}^{\mathrm{R} 451 \mathrm{C}}$ mice. Although zolpidem-induced prolongation of synaptic decay was more pronounced in $\mathrm{NL} 3^{R 451 C} \mathrm{KI}$ micerespect to controls(NL3 ${ }^{\mathrm{R} 451 \mathrm{C}}, 23 \pm 4 \%, n=7 \mathrm{WT}, 14 \pm 2 \%, n=6$; data not shown) this effect did not reach a significant level $(p=0.2$, One-Way ANOVA and Bonferroni post test for multi comparison analysis between groups).

\section{THE NL3 ${ }^{\text {R451C }}$ KI MUTATION DOES NOT ALTER THE TONIC GABA $_{A}$-MEDIATED CONDUCTANCE}

Once released, GABA rapidly diffuses across the synaptic cleft to occupy synaptic $\mathrm{GABA}_{\mathrm{A}}$ receptors. Part of the neurotransmitter escapes the cleft and invades the extracellular space to occupy extrasynaptic high affinity receptors and to generate a persistent $\mathrm{GABA}_{\mathrm{A}}$-mediated conductance (Farrant and Nusser, 2005) which is involved in a number of physiological and pathological processes (Brickley and Mody, 2012). Recent studies have demonstrated a down-regulation of $\mathrm{GABA}_{\mathrm{A}}$-mediated tonic conductance in an animal model of X Fragile syndrome, a common inherited cause of mental retardation with language deficit and
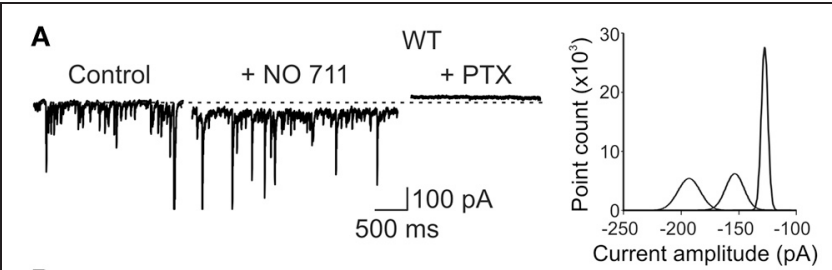

B
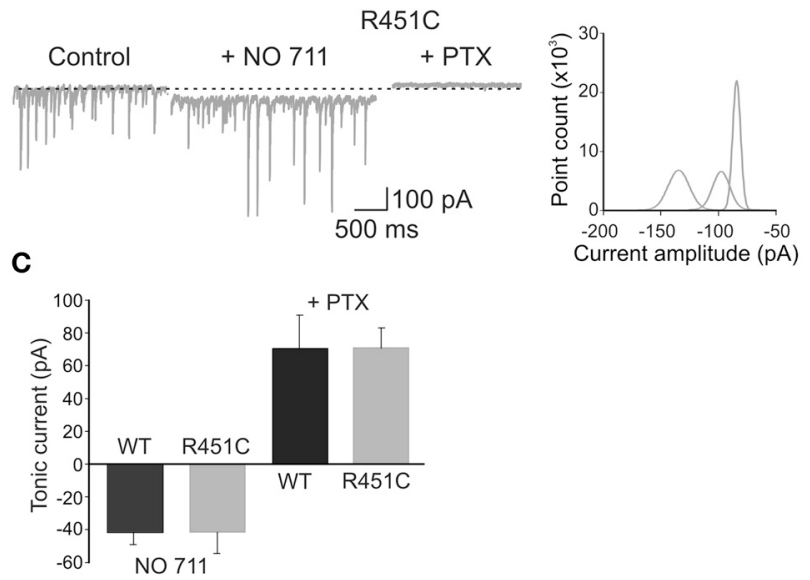

FIGURE 7 | The NL3 ${ }^{\mathrm{R} 451 \mathrm{C}}$ knock-in mutation does not alter GABA transporters and tonic $\mathrm{GABA}_{\mathrm{A}}$-mediated inhibition. (A) Left: representative traces of spontaneous GPSCs recorded in a P 12 pyramidal cell in hippocampal slice obtained from a WT animal before (Control), during application of the GAT-1 blocker NO-711 $(10 \mu \mathrm{M})$ and NO-711 plus picrotoxin $(100 \mu \mathrm{M})$. Right: all-point histogram of $10 \mathrm{~ms}$ traces from the cell recorded on the left in control conditions, in the presence of NO-711 and NO-711 plus picrotoxin. (B) As in (A) but from NL3 ${ }^{\mathrm{R} 451 \mathrm{C}} \mathrm{KI}$ mutant mouse. (C) Summary data obtained from WT (black; $n=6$ ) and NL3 ${ }^{\text {R451C }}$ knock-in mutant mice (gray; $n=7$ ).

autistic behavior (Curia et al., 2009; Olmos-Serrano et al., 2010). Therefore, in the following experiments we searched for differences in $\mathrm{GABA}_{\mathrm{A}}$-mediated tonic conductance between WT and $\mathrm{NL} 3^{\mathrm{R} 451 \mathrm{C}}$ mice. The tonic conductance was obtained by measuring the shift in the holding current following the application of the $\mathrm{GABA}_{\mathrm{A}}$ receptor channel blocker picrotoxin $(100 \mu \mathrm{M})$. This drug caused a similar shift in holding current in WT and in $\mathrm{NL}^{\mathrm{R} 451 \mathrm{C}}$ mice $(54 \pm 11 \mathrm{pA}, n=11$, and $49 \pm 15 \mathrm{pA}, n=6$, in $\mathrm{WT}$ and in $\mathrm{NL}^{\mathrm{R} 451 \mathrm{C}}$ mice, respectively; $p=0.8$; data not shown).

Furthermore, to test whether GABA transporters differentially affect ambient GABA in WT and NL3 ${ }^{\mathrm{R} 451 \mathrm{C}}$ mice, we applied NO-711, which selectively blocks the neuronal and glial GABA transporter GAT-1 (Borden, 1996; Semyanov et al., 2004). NO$711(10 \mu \mathrm{M})$ produced a similar inward shift of the baseline current in both WT and $\mathrm{NL}^{\mathrm{R} 451 \mathrm{C}}$ mice $(41.5 \pm 12.8 \mathrm{pA}$ and $42 \pm 7.5 \mathrm{pA}$ in WT, $n=6$, and knock-in animals, respectively; $n=7 ; p=0.7$ in both; Figures 7A-C). Addition of picrotoxin caused in the two genotypes a similar outward shift in baseline currents $(71 \pm 20 \mathrm{pA} ; n=6$ and $71 \pm 12 \mathrm{pA} ; n=7$; in WT and in $\mathrm{NL} 3^{\mathrm{R} 451 \mathrm{C}}$ mice, respectively, $p=0.98$ ). These data indicate that the $\mathrm{NL}^{\mathrm{R} 451 \mathrm{C}}$ mutation does not affect GABA transporters and the tonic $\mathrm{GABA}_{\mathrm{A}}$-mediated conductance. 


\section{DISCUSSION}

The present results provide evidence that the $\mathrm{NL}^{\mathrm{R} 451 \mathrm{C}}$ mutation selectively affects correlated network activity and GABAergic signaling in the hippocampus already at birth. A previous study from layer $2 / 3$ pyramidal neurons in acute slices of somatosensory cortex obtained from juvenile (P13-P16) NL3 ${ }^{\mathrm{R} 451 \mathrm{C}} \mathrm{KI}$ mice has revealed an increased inhibitory synaptic transmission. These animals exhibited enhanced spatial learning abilities associated with deficits in social interaction [(Tabuchi et al., 2007); but see Chadman et al. (2008) for the behavioral phenotype], reminiscent of those found in some patients affected by ASD. The authors suggested that the NL3 mutation enhances GABAergic transmission without changing the release probability since they failed, at least in the barrel cortex, to detect major modifications in short-term synaptic plasticity.

Our data on GDPs indicate that the $\mathrm{NL} 3^{\mathrm{R} 451 \mathrm{C}}$ mutation affects GABA release. During the first week of postnatal life, GDPs are generated by the interplay between GABA and glutamate, both of them depolarizing and excitatory. Therefore, changes in frequency and shape of spontaneous giant events can be attributed to modifications of the GABAergic, glutamatergic drive to principal cells or in both. A close examination of spontaneous miniature events, occurring during the first week of postnatal life, revealed an increase in frequency, but not in amplitude of mGPSCs, suggesting a presynaptic type of action. This was further supported by TPMPA experiments that, as expected for an enhanced GABA transient in the cleft, showed a reduced blocking effect of the fast-off $\mathrm{GABA}_{\mathrm{A}}$ antagonist on miniature events in NL3 ${ }^{\mathrm{R} 451 \mathrm{C}} \mathrm{KI}$ mice.

Although an increased number of available postsynaptic $\mathrm{GABA}_{\mathrm{A}}$ receptors, may account for these results (on the assumption that these are not saturated by the release of GABA from a single vesicle; Barberis et al., 2004; Hartman et al., 2006), this was not the case since a similar number of receptor channels was revealed with peak-scaled non-stationary fluctuation analysis in both WT and NL3 ${ }^{\mathrm{R} 451 \mathrm{C}}$ knock-in mice. Presynaptic changes in GABA release can be attributed to modifications in the probability of GABA release or in the number of release sites. Considering that miniature events are generated by the release of a single quantum, it seems more likely that an increased number of release sites contributes to the observed effects. This is supported by previous data from Südhof group showing an enhancement of the presynaptic GABAergic marker VGAT (but not VGlut1) in the hippocampus of NL3 ${ }^{\mathrm{R} 451 \mathrm{C}}$ KI mice (Tabuchi et al., 2007) respect to controls.

In the present experiments we did not characterize which subtype of GABAergic interneuron was involved in the observed effects. Although parvalbumin-positive basket cells certainly contribute to the spontaneous action potential-independent release of GABA (Freund and Katona, 2007) we cannot exclude the participation of other interneuron subtypes. In the hippocampus, parvalbumin-positive cells, already present at birth (Bonifazi et al., 2009) play a crucial role in coordinating the timing of neuronal activity, thus contributing to generate theta and gamma rhythms involved in high cognitive functions (Bartos et al., 2007; Klausberger and Somogyi, 2008; Wulff et al., 2009). In some animal models of ASDs (NL3 ${ }^{\mathrm{R} 451 \mathrm{C}}$ knock-in mice and rats prenatally exposed to the histone deacetylase inhibitor, valproate) an asymmetric reduced expression of parvalbuminpositive interneurons across hemispheres has been detected (Gogolla et al., 2009). Since parvalbumin-positive neurons normally drive experience-dependent circuit development (Fagiolini et al., 2004; Hensch, 2005), the selective disruption of these cells may alter neuronal networks during a critical period of postnatal development (Pizzarelli and Cherubini, 2011). Whatever is the subtype of GABAergic interneuron involved, the present data unveil an alteration of the excitatory/inhibitory balance, known to exert a key role in the refinement of cortical circuits early in postnatal life (LeBlanc and Fagiolini, 2011).

It is worth noting that at P27-P35 (and not at early developmental stages), the increased frequency of miniature GABAergic currents paralleled that of miniature glutamatergic events. Although the cause of this effect is presently unclear, as a matter of speculation we can hypothesize that this represents a form of compensatory mechanism developed to counter the early impairment of GABAergic transmission. In this respect, the possibility that changes in the expression of AMPA- and NMDAreceptors containing the NR2B subunits, observed in the adult hippocampus may underlie the same phenomenon, cannot be excluded (Etherton et al., 2011). Alternatively, we cannot exclude that the NL3 mutation affects glutamatergic synaptic transmission only at late developmental stages when reactive plasticity is more pronounced (Groc et al., 2006).

Interestingly, as compared to WT animals, $\mathrm{NL}^{\mathrm{R} 451 \mathrm{C}}$ knock-in mice exhibited mGPSCs with faster decay kinetics, suggesting a possible postsynaptic effect (Barberis et al., 2011). One possibility is that the NL3 mutation affects receptor trafficking, facilitating the recruitment of $\alpha 1$ receptor containing subunits at mutated synapses. However, the lack of significantly different responses to zolpidem between WT and NL3 ${ }^{\mathrm{R} 451 \mathrm{C}}$ KI mice allows excluding this possibility. Although other receptor subtypes may account for the observed effects, we cannot exclude that a fast entrance into the desensitized state of $\mathrm{GABA}_{\mathrm{A}}$ receptors exposed to an increased amount of GABA may account for the acceleration of mGPSCs decay in $\mathrm{NL} 3^{\mathrm{R} 451 \mathrm{C}} \mathrm{KI}$ mice.

How does the E/I balance regulate brain functions? Recent studies have highlighted the role of trans-synaptic signaling via NLs and Nrxs in assembling and stabilizing pre and postsynaptic components (Südhof, 2008). In particular, the NLs which in vertebrate are encoded by four genes (Nlgn1-4 with various splice variants) form homo-dimers through their extracellular domains (Missler et al., 2012). While NL1 is preferentially associated with glutamatergic synapses (Song et al., 1999), NL2 and NL4 with GABAergic synapses (Graf et al., 2004; Varoqueaux et al., 2004; Dong et al., 2007; Hoon et al., 2011). Interestingly, we have recently found that gephyrin, a core protein of inhibitory postsynaptic densities that interacts with the cytoskeleton to stabilize inhibitory receptors in precise opposition to presynaptic active zones, transynaptically acts via NL2 on GABA release, thus directly contributing to maintain an appropriate E/I balance (Marchionni et al., 2009; Varley et al., 2011). Hampering gephyrin function not only alters $\mathrm{GABA}_{\mathrm{A}}$ receptors clusterization and their gating properties but also the probability of GABA 
release, an effect mediated by NL2 since it could be rescued by over expressing this protein in gephyrin-deprived neurons (Varley et al., 2011). Although NL3 is highly expressed in the brain where is localized at both excitatory and inhibitory synapses (Budreck and Scheiffele, 2007), its functional role remains to be elucidated. However, the developmental pattern of NL3 expression, whose peak is coincident with that of synaptogenesis strongly suggests the involvement of this protein in synapse formation and stabilization.

It is worth noting that although mutated NL genes or associated proteins have been found only in a small number of young patients, they provide crucial information on the synaptic abnormalities which possibly affect ASDs.

\section{REFERENCES}

Allene, C., Picardo, M. A., Becq, H., Miyoshi, G., Fishell, G., and Cossart, R. (2012). Dynamic changes in interneuron morphophysiological properties mark the maturation of hippocampal network activity. J. Neurosci. 32, 6688-6698. doi: 10.1523/JNEUROSCI.0081-12.2012 Amaral, D. G., and Dent, J. A. (1981). Development of the mossy fibers of the dentate gyrus: I. A light and electron microscopic study of the mossy fibers and their expansions. J. Comp. Neurol. 195, 51-86. doi: 10.1002/cne.901950106

American Psychiatric Association. (2000). Diagnostic and Statistical manual of Mental Disorders. Washington, DC: American Psychiatric Association.

Barberis, A., Cherubini, E., and Mozrzymas, J. W. (2000). Zinc inhibits miniature GABAergic currents by allosteric modulation of GABAA receptor gating. J. Neurosci. 20, 8618-8627.

Barberis, A., Petrini, E. M., and Cherubini, E. (2004). Presynaptic source of quantal size variability at GABAergic synapses in rat hippocampal neurons in culture. Eur. J. Neurosci. 20, 1803-1810. doi: 10.1111/j.1460-9568.2004.03624.x

Barberis, A., Petrini, E. M., and Mozrzymas, J. W. (2011). Impact of synaptic neurotransmitter concentration time course on the kinetics and pharmacological modulation of inhibitory synaptic currents. Front. Cell. Neurosci. 5:6. doi: 10.3389/fncel.2011.00006

Bartos, M., Vida, I., and Jonas, P. (2007). Synaptic mechanisms of synchronized gamma oscillations in inhibitory interneuron networks. Nat. Rev. Neurosci. 8, 45-56. doi: 10.1038/nrn2044

Ben-Ari, Y., Cherubini, E., Corradetti, R., and Gaiarsa, J. L. (1989).
Giant synaptic potentials in immature rat CA3 hippocampal neurones. J. Physiol. 416, 303-325.

Ben-Ari, Y., Gaiarsa, J. L., Tyzio, R., and Khazipov, R. (2007). GABA: a pioneer transmitter that excites immature neurons and generates primitive oscillations. Physiol. Rev. 87, 1215-1284. doi: 10.1152/physrev.00017.2006

Blankenship, A. G., and Feller, M. B. (2010). Mechanisms underlying spontaneous patterned activity in developing neural circuits. Nat. Rev. Neurosci. 11, 18-29. doi: 10.1038/nrn2759

Bonifazi, P., Goldin, M., Picardo, M. A., Jorquera, I., Cattani, A., Bianconi, G., et al. (2009). GABAergic hub neurons orchestrate synchrony in developing hippocampal networks. Science 326, 1419-1424. doi: 10.1126/science.1175509

Borden, L. A. (1996). GABA transporter heterogeneity: pharmacology and cellular localization. Neurochem. Int. 29, 335-356. doi: 10.1016/0197-0186(95)00158-1

Brickley, S. G., and Mody, I. (2012). Extrasynaptic GABAA$\mathrm{R}$ : their function in the CNS and Implications for disease. Neuron 73, 23-34. doi: 10.1016/j.neuron.2011.12.012

Budreck, E. C., and Scheiffele, P. (2007). Neuroligin 3 is a neuronal adhesion protein at GABAergic and glutamatergic synapses. Eur. J. Neurosci. 26, 1738-1748. doi: 10.1111/j.14609568.2007.05842.x

Cathala, L., Brickley, S., Cull-Candy, S., and Farrant, M. (2003). Maturation of EPSCs and intrinsic membrane properties enhances precision at a cerebellar synapse. J. Neurosci. 23, 6074-6085.

Chadman, K. K., Gong, S., Scattoni, M. L., Boltuck, S. E., Gandhy, S. U., Heintz, N., et al. (2008). Minimal

\section{AUTHOR CONTRIBUTIONS}

Enrico Cherubini and Rocco Pizzarelli: conceived and designed the experiments. Rocco Pizzarelli: performed the experiments, analyzed data. Enrico Cherubini: wrote the paper. Both authors approved the final version of the manuscript.

\section{ACKNOWLEDGMENTS}

The authors are grateful to Drs. Andrea Barberis and Paola Zacchi for useful suggestions and for carefully reading the manuscript; to Jessica Franzot for genotyping. This study was supported by a Telethon grant (GGP11043) and a grant from Ministero dell'Istruzione, dell'Universita' e della Ricerca (PRIN 2011) to Enrico Cherubini.

aberrant behavioral phenotypes of neuroligin-3 R451C knockin mice. Autism Res. 1, 147-158. doi: 10.1002/aur.22

Cherubini, E., and Conti, F. (2001). Generating diversity at GABAergic synapses. Trends Neurosci. 24, 155-162. doi: 10.1016/S0166-2236(00)01724-0

Cherubini, E., Gaiarsa, J. L., and BenAri, Y. (1991). GABA: an excitatory transmitter in early postnatal life. Trends Neurosci. 14, 515-519. doi: 10.1016/0166-2236(91)90003-D

Chubykin, A. A., Atasoy, D., Etherton, M. R., Brose, N., Kavalali, E., Gibson, J. R., et al. (2007). Activitydependent validation of excitatory versus inhibitory synapses by neuroligin-1 versus neuroligin2. Neuron 54, 919-931. doi: 10.1016/j.neuron.2007.05.029

Curia, G., Papouin, T., Séguéla, P., and Avoli, M. (2009). Downregulation of tonic GABAergic inhibition in a mouse model of fragile $\mathrm{X}$ syndrome. Cereb. Cortex 19, 1515-1520. doi: 10.1093/cercor/bhn159

Dong, N., Qi, J., and Chen, G. (2007). Molecular reconstitution of functional GABAergic synapses with expression of neuroligin2 and GABAA receptors. Mol. Cell. Neurosci. 35, 14-23. doi: 10.1016/j.mcn.2007.01.013

Durand, C. M., Betancur, C., Boeckers, T. M., Bockmann, J., Chaste, P., Fauchereau, F., et al. (2007). Mutations in the gene encoding the synaptic scaffolding protein SHANK3 are associated with autism spectrum disorders. Nat. Genet. 39, 25-27. doi: 10.1038/ng1933

Dzhala, V. I., Talos, D. M., Sdrulla, D. A., Brumback, A. C., Mathews, G. C., Benke, T. A., et al. (2005). NKCC1 transporter facilitates seizures in the developing brain. Nat. Med. 11, 1205-1213. doi: $10.1038 / \mathrm{nm} 1301$
Etherton, M., Földy, C., Sharma, M., Tabuchi, K., Liu, X., Shamloo, M., et al. (2011). Autism-linked neuroligin-3 R451C mutation differentially alters hippocampal and cortical synaptic function. Proc. Natl. Acad. Sci. U.S.A. 108, 13764-13769. doi: 10.1073/pnas.1111093108

Fagiolini, M., Fritschy, J. M., Löw, K., Möhler, H., Rudolph, U., and Hensch, T. K. (2004). Specific GABAA circuits for visual cortical plasticity. Science 303, 1681-1683. doi: 10.1126/science.1091032

Farrant, M., and Nusser, Z. (2005). Variations on an inhibitory theme: phasic and tonic activation of $\operatorname{GABA}(\mathrm{A})$ receptors. Nat. Rev. Neurosci. 6, 215-229. doi: 10.1038/nrn1625

Freund, T. F., and Katona, I. (2007). Perisomatic inhibition. Neuron 56, 33-42. doi: 10.1016/j.neuron.2007.09.012

Fu, Z., Washbourne, P., Ortinski, P., and Vicini, S. (2003). Functional excitatory synapses in HEK293 cells expressing neuroligin and glutamate receptors. J. Neurophysiol. 90, 3950-3957. doi: 10.1152/jn.00647.2003

Geschwind, D. H., and Levitt, P. (2007). Autism spectrum disorders: developmental disconnection syndromes. Curr. Opin. Neurobiol. 17, 103-111. doi: 10.1016/j.conb.2007.01.009

Glykys, J., and Mody, I. (2007). The main source of ambient GABA responsible for tonic inhibition in the mouse hippocampus. J. Physiol. 582, 1163-1178. doi: 10.1113/jphysiol.2007.134460

Gogolla, N., Leblanc, J. J., Quast, K. B., Südhof, T. C., Fagiolini, M., and Hensch, T. K. (2009). Common circuit defect of excitatory-inhibitory balance in mouse models of autism. J. Neurodev. Disord. 1, 
172-181. doi: 10.1007/s11689-0099023-x

Graf, E. R., Zhang, X., Jin, S. X., Linhoff, M. W., and Craig, A. M. (2004). Neurexins induce differentiation of GABA and glutamate postsynaptic specializations via neuroligins. Cell 119, 1013-1026. doi: 10.1016/j.cell.2004.11.035

Griguoli, M., Maul, A., Nguyen, C., Giorgetti, A., Carloni, P., and Cherubini, E. (2010). Nicotine blocks the hyperpolarizationactivated current Ih and severely impairs the oscillatory behavior of oriens-lacunosum moleculare interneurons. J. Neurosci. 30, 10773-10783. doi: 10.1523/JNEUROSCI.2446-10.2010

Groc, L., Gustafsson, B., and Hanse, E. (2006). AMPA signalling in nascent glutamatergic synapses: there and not there! Trends Neurosci. 29, 132-139. doi: 10.1016/j.tins.2006.01.005

Hartman, K. N., Pal, S. K., Burrone, J., and Murthy, V. N. (2006). Activitydependent regulation of inhibitory synaptic transmission in hippocampal neurons. Nat. Neurosci. 9, 642-649. doi: 10.1038/nn1677

Hensch, T. K. (2005). Critical period plasticity in local cortical circuits. Nat. Rev. Neurosci. 6, 877-888. doi: 10.1038/nrn1787

Hoon, M., Soykan, T., Falkenburger, B., Hammer, M., Patrizi, A., Schmidt, K. F., et al. (2011). Neuroligin4 is localized to glycinergic postsynapses and regulates inhibition in the retina. Proc. Natl. Acad. Sci. U.S.A. 108, 3053-3058. doi: 10.1073/pnas.1006946108

Jamain, S., Quach, H., Betancur, C., Rastam, M., Colineaux, C., Gillberg, I. C., et al. (2003). Mutations of the $\mathrm{x}$-linked genes encoding neuroligins NLGN3 and NLGN4 are associated with autism. Nat. Genet. 34, 27-29. doi: $10.1038 /$ ng1136

Jones, M. V., Jonas, P., Sahara, Y., and Westbrook, G. L. (2001). Microscopic kinetics and energetics distinguish GABAA receptor agonists from antagonists. Biophys. J. 81, 2660-2670. doi: 10.1016/S0006-3495(01)75909-7

Katz, B. (1969). The Release of Neural Transmitter Substances. Liverpool: Liverpool University Press.

Kim, H. G., Kishikawa, S., Higgins, A. W., Seong, I. S., Donovan, D. J., Shen, Y., et al. (2008). Disruption of neurexin 1 associated with autism spectrum disorder. Am. J. Hum. Genet. 82, 199-207. doi: 10.1016/j.ajhg.2007.09.011

Klausberger, T., and Somogyi, P. (2008). Neuronal diversity and temporal dynamics: the unity of hippocampal circuit operations. Science 321, 53-57. doi: 10.1126/science.1149381

Ko, J., Zhang, C., Arac, D., Boucard, A. A., Brunger, A. T., and Sudhof, T. C. (2009). Neuroligin-1 performs neurexin-dependent and neurexinindipendent functions in synapses validation. EMBO J. 28, 3244-3255. doi: 10.1038/emboj.2009.249

Laumonnier, F., Bonnet-Brilhault, F., Gomot, M., Blanc, R., David, A., Moizard, M. P., et al. (2004). $\mathrm{X}$-linked mental retardation and autism are associated with a mutation in the NLGN4 gene, a member of the neuroligin family. Am. J. Hum. Genet. 74, 552-557. doi: $10.1086 / 382137$

Laurie, D. J., Wisden, W., and Seeburg, P. H. (1992). The distribution of thirteen GABAA receptor subunit mRNAs in the rat brain. III. Embryonic and postnatal development. J. Neurosci. 12, 4151-4172.

LeBlanc, J. J., and Fagiolini, M. (2011). Autism: a "critical period" disorder? Neural Plast. 2011:921680. doi: 10.1155/2011/921680

Le Magueresse, C., Safiulina, V., Changeux, J. P., and Cherubini, E. (2006). Nicotinic modulation of network and synaptic transmission in the immature hippocampus investigated with genetically modified mice. J. Physiol. 576, 533-546. doi: 10.1113/jphysiol. 2006.117572

Marchionni, I., Kasap, Z., Mozrzymas, J. W., Sieghart, W., Cherubini, E., and Zacchi, P. (2009). New insights on the role of gephyrin in regulating both phasic and tonic GABAergic inhibition in rat hippocampal neurons in culture. Neuroscience 164, 552-562. doi: 10.1016/j.neuroscience.2009.07.063

Missler, M., Südhof, T. C., and Biederer, T. (2012). Synaptic cell adhesion. Cold Spring Harb. Perspect. Biol. 4:a005694. doi: 10.1101/cshperspect.a005694

Momiyama, A., Silver, R. A., Hausser, M., Notomi, T., Wu, Y., Shigemoto, R., et al. (2003). The density of AMPA receptors activated by a transmitter quantum at the climbing fibre-Purkinje cell synapse in immature rats. J. Physiol. 549, 75-92. doi: 10.1113/jphysiol.2002.033472

Mozrzymas, J. W., Barberis, A., Michalak, K., and Cherubini, E. (1999). Chlorpromazine inhibits miniature GABAergic currents by reducing the binding and by increasing the unbinding rate of
GABAA receptors. J. Neurosci. 19 , 2474-2488.

Olmos-Serrano, J. L., Paluszkiewicz, S. M., Martin, B. S., Kaufmann, W. E., Corbin, J. G., and Huntsman, M. M. (2010). Defective GABAergic neurotransmission and pharmacological rescue of neuronal hyperexcitability in the amygdala in a mouse model of fragile $\mathrm{X}$ syndrome. J. Neurosci. 30, 9929-9938. doi: 10.1523/JNEUROSCI.1714-10.2010

Perrais, D., and Ropert, N. (1999). Effect of zolpidem on miniature IPSCs and occupancy of postsynaptic GABAA receptors in central synapses. J. Neurosci. 19, 578-588.

Picardo, M. A., Guigue, P., Bonifazi, P., Batista-Brito, R., Allene, C., Ribas, A., et al. (2011). Pioneer GABA cells comprise a subpopulation of hub neurons in the developing hippocampus. Neuron 71, 695-709. doi: 10.1016/j.neuron. 2011.06 .018

Pizzarelli, R., and Cherubini, E. (2011). Alterations of GABAergic signaling in Autism Spectrum Disorders. Neural Plast. 2011:297153. doi: 10.1155/2011/297153

Poulopoulus, A., Aramuni, G. Meyer, G., Soykan, T., Hoon, M., Papadopoulos, T., et al. (2009). Neuroligin2 drives postsynaptic assembly at perisomatic inhibitory synapses through gephyrin and collybistin. Neuron 63, 628-642. doi: 10.1016/j.neuron.2009.08.023

Pritchett, D. B., and Seeburg, P. H (1990). Gamma-aminobutyric acidA receptor alpha 5-subunit creates novel type II benzodiazepine receptor pharmacology. J. Neurochem. 54, 1802-1804.

Safiulina, V. F., Zacchi, P., Taglialatela, M., Yaari, Y., and Cherubini, E. (2008). Low expression of Kv7/M channels facilitates intrinsic and network bursting in the developing rat hippocampus. J. Physiol. 586, 5437-5453. doi: 10.1113/jphysiol.2008.156257

Sara, Y., Biederer, T., Atasoy, D., Chubykin, A., Mozhayeva, M. G., Südhof, T. C., et al. (2005). Selective capability of SynCAM and neuroligin for functional synapse assembly. J. Neurosci. 25, 260-270. doi: 10.1523/JNEUROSCI.3165-04.2005

Scheiffele, P., Fan, J., Choih, J., Fetter, R., and Serafini, T. (2000). Neuroligin expressed in nonneuronal cells triggers presynaptic development in contacting axons. Cell 101, 657-669. doi: 10.1016/S0092-8674(00)80877-6

Semyanov, A., Walker, M. C., Kullmann, D. M., and Silver,
R. A. (2004). Tonically active GABA A receptors: modulating gain and maintaining the tone. Trends Neurosci. 27, 262-269. doi: 10.1016/j.tins.2004.03.005

Sipila, S. T., Schuchmann, S., Voipio, J., Yamada, J., and Kaila, K. (2006). The cation-chloride cotransporter NKCC1 promotes sharp waves in the neonatal rat hippocampus. J. Physiol. 573, 765-773. doi: 10.1113/jphysiol.2006.107086

Song, J. Y., Ichtchenko, K., Sudhof, T. C., and Brose, N. (1999). Neuroligin1 is a postsynaptic cell adhesion molecule of excitatory synapses. Proc. Natl. Acad. Sci. U.S.A. 108, 16502-16509. doi: 10.1073/pnas.96.3.1100

Südhof, T. C. (2008). Neuroligins and neurexins link synaptic function to cognitive disease. Nature 455, 903-911. doi: 10.1038/nature07456

Tabuchi, K., Blundell, J., Etherton, M. R., Hammer, R. E., Liu, X., Powell, C. M., et al. (2007). A neuroligin3 mutation implicated in autism increases inhibitory synaptic transmission in mice Science 318, 71-76. doi: 10.1126/science.1146221

Traynelis, S. F., Silver, R. A., and Cull-Candy, S. G. (1993). Estimated conductance of glutamate receptor channels activated during EPSCs at the cerebellar mossy fiber-granule cell synapse. Neuron 11, 279-289. doi: 10.1016/0896-6273(93)90184-S

Varley, Z. K., Pizzarelli, R., Antonelli, R., Stancheva, S. H., Kneussel, M., Cherubini, E., et al. (2011). Gephyrin regulates GABAergic and glutamatergic synaptic transmission in hippocampal cell cultures. J. Biol. Chem. 286, 20942-20951. doi: 10.1074/jbc.M111.234641

Varoqueaux, F., Aramuni, G., Rawson, R. L., Mohrmann, R., Missler, M., Gottmann, K., et al. (2006). Neuroligins determines synapses maturation and function. Neuron 51, 741-754. doi: 10.1016/j.neuron.2006.09.003

Varoqueaux, F., Jamain, S., and Brose, N. (2004). Neuroligin 2 is exclusively localized to inhibitory synapses. Eur. J. Cell Biol. 83, 449-456. doi: 10.1078/0171-9335-00410

Weintraub, K. (2011). The prevalence puzzle: autism counts. Nature 479 22-24. doi: 10.1038/479022a

Wulff, P., Ponomarenko, A. A., Bartos, M., Korotkova, T. M., Fuchs, E. C., Bähner, F., et al. (2009). Hippocampal theta rhythm and its coupling with gamma oscillations require fast inhibition onto parvalbumin-positive interneurons. Proc. Natl. Acad. 
Sci. U.S.A. 106, 3561-3566. doi: $10.1073 /$ pnas.0813176106

Yan, J., Oliveira, G., Coutinho, A., Yang, C., Feng, J., Katz, C., et al. (2005). Analysis of the neuroligin 3 and 4 genes in autism and other neuropsychiatric patients. Mol. Psychiatry 10, 329-332. doi: 10.1038/sj.mp.4001629
Conflict of Interest Statement: The authors declare that the research was conducted in the absence of any commercial or financial relationships that could be construed as a potential conflict of interest.

Received: 13 March 2013; paper pending published: 17 April 2013; accepted:
17 May 2013; published online: 04 June 2013.

Citation: Pizzarelli $R$ and Cherubini E (2013) Developmental regulation of GABAergic signalling in the hippocampus of neuroligin 3 R451C knock-in mice: an animal model of Autism. Front. Cell. Neurosci. 7:85. doi: 10.3389/fncel. 2013.00085
Copyright (C) 2013 Pizzarelli and Cherubini. This is an open-access article distributed under the terms of the Creative Commons Attribution License, which permits use, distribution and reproduction in other forums, provided the original authors and source are credited and subject to any copyright notices concerning any third-party graphics etc. 